\title{
Zinc Induced Enzymatic Defense Mechanisms in Rhizoctonia Root Rot Infected Clusterbean Seedlings
}

\author{
Neha Wadhwa, ${ }^{1}$ Udai Narayan Joshi, ${ }^{1}$ and Naresh Mehta $^{2}$ \\ ${ }^{1}$ Department of Biochemistry, CCS Haryana Agricultural University, Hisar, Haryana 125004, India \\ ${ }^{2}$ Department of Pathology, CCS Haryana Agricultural University, Hisar, Haryana 125004, India
}

Correspondence should be addressed to Udai Narayan Joshi; unjoshi2007@rediffmail.com

Received 25 February 2014; Revised 6 May 2014; Accepted 9 May 2014; Published 26 May 2014

Academic Editor: Urs Feller

Copyright (C) 2014 Neha Wadhwa et al. This is an open access article distributed under the Creative Commons Attribution License, which permits unrestricted use, distribution, and reproduction in any medium, provided the original work is properly cited.

\begin{abstract}
This investigation was planned to determine the effect of different concentrations of zinc ( $\mathrm{Zn}$ ) on biochemical constituents of clusterbean, which play an important role in disease resistance mechanisms. Clusterbean seedlings were grown with 0 , 10, or $20 \mathrm{mg} \mathrm{Zn} \mathrm{kg}^{-1}$ soil treatments in earthen pots filled with $700 \mathrm{~g}$ inoculated soil. Soil was inoculated by pretreatment with $250 \mathrm{mg}$ (wet weight) of Rhizoctonia inoculums per pot. A similar set was maintained in uninoculated soil. Root rot incidence decreased to 41 and 27 per cent with 10 and $20 \mathrm{mg} \mathrm{Zn} \mathrm{kg}^{-1}$ soil treatments, respectively, as compared to 68 percent at control. Antioxidative enzyme activity (polyphenol oxidase, peroxidase, phenylalanine ammonia lyase, and tyrosine ammonia lyase) increased in inoculated seedlings and was increased further by $20 \mathrm{mg} \mathrm{Zn} \mathrm{kg}^{-1}$ soil treatment. Antioxidative enzymes play an important role against fungal invasion, as peroxidase is involved in the formation of barrier via lignifications at the site of pathogen penetration. PAL and TAL play a key role in phenylpropanoid metabolism and could perform defense-related functions. Zn acts as a cofactor for these enzymes, so it can be concluded that Zn may be used as a soil-nutritive agent to increase resistance in plants against fungal diseases.
\end{abstract}

\section{Introduction}

Clusterbean (Cyamopsis tetragonoloba L.) commonly known as "Guar" is an important annual kharif legume crop of arid and semiarid regions of the country. It is commonly grown in north-western zone of India, namely, Haryana, Rajasthan, Punjab, and parts of U. P. and M. P. [1]. It is mainly grown for feed, green fodder, vegetable, and green manuring [2]. During the growth period, guar plants are attacked by several pathogens which cause root rot and wilt diseases. Many soil-borne fungi such as Rhizoctonia solani, Fusarium solani, Fusarium oxysporum, and Macrophomina phaseolina infect plants to cause damping-off and wilt diseases [3-5]. Root rot is a soil-borne fungal disease that results in damping-off of seedlings. During root rot, reddish brown lesions occur at the collar region as well as on the roots. The main causal agents of dry root rot are Rhizoctonia species. Most farmers use fungicides such as carbendazim to control this disease but their efficacy is greatly altered by soil moisture, temperature, and texture, and thus they often fail to give satisfactory results [6]. With increased utilization of chemical fertilizers and increasing fertilizer prices due to their dependence on fossil fuels, water, air, and soil pollution and ignorance in the use of chemical fertilizers are problems that must be solved with appropriate methods. Today world policy encourages minimum utilization of chemical fertilizers and pesticides as they result in a diversity of adverse problems such as threats to ecosystem and human health, increase in production costs, and induction of pathogen resistance to chemicals following their long-term use. Thus, there should be more efficient use of inputs to avoid pest tolerance, reduce environmental risk, and improve human health. It is, therefore, beneficial to maximize genetic resistance through breeding in order to increase productivity and to reduce disease incidence.

Moreover, productivity and percent disease incidence are influenced by soil nutrients [7]. The role of proper nutrition in preventing disease is often overlooked. Nutrients are important for growth and development of plants and they also play an important role in disease control [8]. Most of the microelements can affect resistance indirectly, and deficient plants become more suitable substrates for pests. 
Microelements are crucial for plant growth since they not only participate in building cell walls, cell membranes $(\mathrm{B}, \mathrm{Zn})$, and enzymes $(\mathrm{Fe}, \mathrm{Mn}, \mathrm{Cu})$ but also affect enzyme activity $(\mathrm{Mn}, \mathrm{Zn})$ and photosynthesis ( $\mathrm{Fe}, \mathrm{Cu}, \mathrm{Mn})$ [9]. Mineral nutrients are the first and foremost line of defense against plant disease as they are involved in the formation of physical barrier against pathogen invasion and thus influence all parts of the disease "pyramid" $[10,11]$. Among micronutrients, zinc is an important element essential for plant growth and metabolism. Plant enzymes activated by $\mathrm{Zn}$ are involved in carbohydrate metabolism, maintenance of the integrity of cellular membranes, protein synthesis, regulation of auxin synthesis, and pollen formation. Apart from this it helps in cell wall development, respiration, photosynthesis, chlorophyll formation, and rate of maturity [12]. Zinc also plays a critical role in plant disease tolerance and should be considered as a preventive solution in disease management plans. Zn had a positive effect on tolerance of wheat against Fusarium solani root rot [13]. Manganese is useful in controlling a number of pathogenic diseases such as powdery mildew, downy mildew, and several other fungal diseases [14-16]. Similar results were found in wheat, where application of $\mathrm{B}, \mathrm{Mn}$, and $\mathrm{Zn}$, separately increased the resistance of plants to the tan spot disease [17]. Despite the fact that the importance of nutrients in disease control has been recognized for some of the most severe diseases, the information regarding the effect of micronutrients on root rot infected clusterbean is scanty. In view of this, the research was planned to determine the effect of different concentrations of zinc $(\mathrm{Zn})$ on biochemical constituents of clusterbean, such as antioxidative enzymes namely peroxidase, polyphenol oxidase, phenylalanine ammonia lyase, and tyrosine ammonia lyase, which play an important role in disease resistance mechanisms. Peroxidase is involved in the formation of barrier via lignifications at the site of pathogen penetration. PAL and TAL play a key role in linking primary metabolism to phenylpropanoid metabolism and could perform defenserelated functions. PAL has been widely studied in plant tissues, especially with regard to its induction by various environmental factors such as light, wound excision, and infection.

\section{Materials and Methods}

2.1. Plant Material and Soil. Seeds of guar genotype, FS 277 (susceptible to root rot), were obtained from Forage Section, Department of Genetics and Plant Breeding, CCSHAU, Hisar. A loamy sand soil was procured from the Regional Research Station, Balsmand of Hisar District. Soil characteristics were $\mathrm{pH}(1: 2)$ 8.3; organic carbon $0.37 \%$; $\mathrm{N} 4.0 \mathrm{mg} \mathrm{kg}^{-1}$ soil; $\mathrm{P}$ $13.0 \mathrm{mg} \mathrm{kg}^{-1}$ soil; $\mathrm{K} 163 \mathrm{mg} \mathrm{kg}^{-1}$ soil; $\mathrm{Zn}^{2+} 0.61 \mathrm{mg} \mathrm{kg}^{-1}$ soil; $\mathrm{Fe}^{2+} 2.62 \mathrm{mg} \mathrm{kg}{ }^{-1}$ soil; $\mathrm{Cu}^{2+} 0.18 \mathrm{mg} \mathrm{kg}^{-1}$ soil; and $\mathrm{Mn}^{2+}$ $3.65 \mathrm{mg} \mathrm{kg}^{-1}$ soil. The metal micronutrients were extracted from the soil sample with DTPA (diethylene triamine petaacetic acid), a chelate designed to extract the most readily available forms of the positively charged metals and were estimated using Atomic Absorption Spectrophotometer. The homogenized and sieved soil was sterilized at $15 \mathrm{lbs} / \mathrm{cm}^{2}$ pressure for $2 \mathrm{~h}$ in an autoclave and filled in earthen pots at the rate of $700 \mathrm{~g}$ soil per pot. Ten pots per treatment were set up and were lined with polythene bags in order to avoid contamination.

2.2. Pathogen. The virulent isolate of Rhizoctonia species was cultured and maintained on potato dextrose agar. Rhizoctonia mycelia were grown for 6 days in potato dextrose broth at $30^{\circ} \mathrm{C}$, harvested, washed, and blended in sterilized deionized water to give $25 \mathrm{gL}^{-1}$ fresh mycelial propagules.

2.3. Soil Inoculation. $10 \mathrm{ml}$ of the mycelial suspension was added to the surface of moist soil of each pot so that each pot received $250 \mathrm{mg}$ (wet weight) of mycelial propagules.

2.4. Treatments. $\mathrm{Zn}$ as $\mathrm{ZnSO}_{4} \cdot 7 \mathrm{H}_{2} \mathrm{O}$ was applied at 0,10 , or $20 \mathrm{mg} \mathrm{kg}^{-1}$ soil as aqueous solutions. A recommended basal dose of $\mathrm{N}\left(12.5 \mathrm{mg} \mathrm{kg}^{-1}\right.$ soil) in the form of urea and $\mathrm{P}$ $\left(31.0 \mathrm{mg} \mathrm{kg}^{-1}\right.$ soil) as potassium dihydrogen orthophosphate was also given. A fungicide control ( $2 \mathrm{~g} / \mathrm{kg}$ carbendazim) was also provided.

Ten seeds of guar (cv. FS 277) were planted in each of the inoculated pots. A similar set of treatments was maintained in uninoculated soil.

2.5. Sampling. Guar seedlings were collected at 15 days after sowing (DAS) and root rot incidence was recorded.

\subsection{Laboratory Studies}

2.6.1. Disease Incidence. Root rot disease incidence was recorded 15 DAS. On the basis of visual observation of symptoms, the percentage disease incidence was calculated by the following formula:

Percent disease incidence

$$
\begin{aligned}
= & \frac{\text { Number of infected seedlings in inoculated treatments }}{\text { Total number of seedlings in inoculated treatments }} \\
& \times 100 .
\end{aligned}
$$

2.6.2. Zinc Concentration. One gram powdered sample was digested with $15 \mathrm{ml}$ of diacid mixture $\left(4 \mathrm{HNO}_{3}: 1 \mathrm{HClO}_{4}\right)$ in a conical flask by heating on hot plate in open space till clear white precipitates settled down at the bottom of the conical flask. The precipitates were then dissolved in $1 \% \mathrm{HCl}$ and filtered and volume of the filtrate was made $50 \mathrm{ml}$ with glass distilled water.

The contents of Zinc ( $\mathrm{Zn}$ ) were then estimated, from the extract prepared, by atomic absorption spectrophotometer (Model PERKIN-ELMER 2380).

\subsubsection{Enzyme Assays}

(1) Preparation of Enzyme Extract. The entire procedure for preparing enzyme extract was done at $0-4^{\circ} \mathrm{C}$. Root tissues were brought to the laboratory in polythene bags buried in 
crushed ice, freed of foreign material by washing thoroughly with tap water followed by distilled water, and blotted dry. One gram of roots was then homogenized in $10 \mathrm{ml} 0.1 \mathrm{M}$ phosphate buffer ( $\mathrm{pH}$ 7.0) in a previously chilled mortar using glass beads as abrasive. The homogenate was then centrifuged at $10,000 \mathrm{rpm}$ for $20 \mathrm{~min}$ in a refrigerated centrifuge at $0-4^{\circ} \mathrm{C}$. The supernatant obtained was referred to as crude extract and stored in a refrigerator for enzyme assays and estimation of total soluble protein. The crude extract was used fresh on the same day for enzyme assays.

(2) Polyphenol Oxidase (E.C. 1.10.3.1). Polyphenol oxidase activity was assayed by the modified method of Taneja and Sachar [18].

The reaction mixture had a final volume of $4 \mathrm{ml}$, contained $1.8 \mathrm{ml}$ of $0.05 \mathrm{M}$ phosphate buffer ( $\mathrm{pH} \mathrm{6.6),} 2 \mathrm{ml}$ of $1 \%$ catechol solution as substrate, and $0.2 \mathrm{ml}$ of enzyme extract. This mixture was incubated at $37^{\circ} \mathrm{C}$ for 1 hour. Absorbance was measured at $430 \mathrm{~nm}$ on a UV-Vis spectrophotometer (Systronic 118). For each sample, a separate blank was run simultaneously by inoculating with boiled enzyme extract. Enzyme activity was expressed as 0.01 change in absorbance $\min ^{-1} \mathrm{mg}^{-1}$ protein.

(3) Peroxidase (E.C. 1.11.1.7). Peroxidase was assayed according to the method of Shannon et al. [19].

The $4 \mathrm{ml}$ final volume reaction mixture contained $0.3 \mathrm{ml}$ of o-dianisidine $(12 \mathrm{mg}$ o-dianisidine dissolved in $5 \mathrm{ml}$ methanol), $0.1 \mathrm{ml}$ of $0.2 \% \mathrm{H}_{2} \mathrm{O}_{2}\left(0.7 \mathrm{ml}\right.$ of $30 \%(\mathrm{w} / \mathrm{v}) \mathrm{H}_{2} \mathrm{O}_{2}$ in $99.3 \mathrm{ml}$ of distilled water), $3.5 \mathrm{ml}$ of $0.1 \mathrm{M}$ citrate buffer ( $\mathrm{pH} 4.8$ ), and $0.1 \mathrm{ml}$ of diluted enzyme extract ( $1 \mathrm{ml}$ of enzyme extract $+9 \mathrm{ml}$ distilled water). The enzymatic reaction was initiated by the addition of $\mathrm{H}_{2} \mathrm{O}_{2}$ and the change in absorbance was followed at $430 \mathrm{~nm}$. Enzyme activity was expressed as the change in 0.01 absorbance $\mathrm{min}^{-1} \mathrm{mg}^{-1}$ protein.

(4) Phenylalanine Ammonia Lyase (E.C. 4.3.1.5). The activity of phenylalanine ammonia lyase (PAL) was measured following the method of Biehn et al. [20].

The reaction mixture consisted of $4 \mathrm{ml}$ of $14 \mathrm{mM}$ phenylalanine $(0.231 \mathrm{~g}$ phenylalanine dissolved in ethanol and volume made to $100 \mathrm{ml}$ with borate buffer, $\mathrm{pH} \mathrm{8.8)}$ and $0.5 \mathrm{ml}$ of the enzyme extract. After incubation at $37^{\circ} \mathrm{C}$ for 2 hours, $0.1 \mathrm{ml}$ of $6 \mathrm{~N} \mathrm{HCl}$ was added to stop the reaction. The contents were then extracted twice with an equal volume of diethyl ether and evaporated to dryness. The residue was dissolved in $10 \mathrm{ml}$ of $50 \mathrm{mM} \mathrm{NaOH}(2 \mathrm{~g} / \mathrm{L})$ and absorbance was read at $290 \mathrm{~nm}$. A blank with the reaction stopped prior to incubation by the addition of $0.1 \mathrm{ml}$ of $6 \mathrm{~N} \mathrm{HCl}$ was run simultaneously. Enzyme activity was expressed in units with 1 unit $=1 \mu$ mole $\mathrm{t}$-cinnamate accumulated $\mathrm{h}^{-1} \mathrm{mg}^{-1}$ protein.

(5) Tyrosine Ammonia Lyase (E.C. 4.3.1.7). Tyrosine ammonia lyase (TAL) activity was measured following the method of Biehn et al. [20].

The procedure was similar to that for PAL except that $14 \mathrm{mM}$ tyrosine was used as the substrate instead of $14 \mathrm{mM}$ phenylalanine.
The reaction mixture consisted of $4 \mathrm{ml}$ of $14 \mathrm{mM}$ tyrosine ( $0.253 \mathrm{~g}$ tyrosine dissolved in ethanol and made to $100 \mathrm{ml}$ with borate buffer, $\mathrm{pH} 8.8$ ) and $0.5 \mathrm{ml}$ of the enzyme extract. After incubation at $37^{\circ} \mathrm{C}$ for 2 hours, $0.1 \mathrm{ml}$ of $6 \mathrm{~N} \mathrm{HCl}$ was added to stop the reaction. The solution was extracted twice with an equal volume of diethyl ether and evaporated to dryness. The residue was dissolved in $10 \mathrm{ml}$ of $50 \mathrm{mM} \mathrm{NaOH}(2 \mathrm{~g} / \mathrm{L})$ and absorbance was read at $333 \mathrm{~nm}$. A blank with the reaction stopped prior to incubation by addition of $0.1 \mathrm{ml}$ of $6 \mathrm{~N} \mathrm{HCl}$ was run simultaneously. Enzyme activity was expressed as 1 unit $=1 \mu$ mole coumaric acid accumulated $\mathrm{h}^{-1} \mathrm{mg}^{-1}$ protein.

(6) Soluble Protein. The soluble protein in the enzyme extract was precipitated by $20 \%$ trichloro acetic acid (TCA), centrifuged and residue dissolved in $0.1 \mathrm{~N}$ sodium hydroxide $(\mathrm{NaOH})$ solution, and was determined by the method of Lowry et al. [21]:

Reagent A: $2 \%$ sodium carbonate in $0.1 \mathrm{~N}$ sodium hydroxide;

Reagent B: $0.5 \%$ copper sulphate in $1 \%$ sodiumpotassium tartrate;

Reagent C: prepared by mixing $50 \mathrm{ml}$ of reagent $\mathrm{A}$ with $1 \mathrm{ml}$ of reagent $\mathrm{B}$. This reagent was prepared at the time of use;

Reagent D: Folin-Ciocalteau reagent diluted with water $1: 1$ ratio.

To $1 \mathrm{ml}$ extract of the solubilized protein, obtained after precipitation, $5 \mathrm{ml}$ of reagent $\mathrm{C}$ was added. To this, $0.5 \mathrm{ml}$ of reagent $\mathrm{D}$ was added with simultaneous mixing. After $30 \mathrm{~min}$, the absorbance was read at $660 \mathrm{~nm}$. The protein content in $\mathrm{mg} \mathrm{g}^{-1}$ fresh weight of the tissue was calculated by calibrating the absorbance with bovine serum albumin as standard.

2.7. Statistical Analysis. The experimental data was analyzed as a completely randomized block (CRD) design using OPSTAT software available on the CCSHAU home page [22].

\section{Results}

3.1. Disease Incidence. Reddish brown lesions appeared from Rhizoctonia infection on the collar region and roots of guar 15 DAS (Figure 1).

Disease incidence of seedlings growing in soil with Rhizoctonia decreased to 41 and 27 per cent with 10 and $20 \mathrm{mg}$ $\mathrm{Zn} \mathrm{kg}^{-1}$ soil, respectively, as compared with 68 per cent at control (Table 1). Disease incidence was also decreased to 27 percent with the carbendazim treatment. Percent disease incidence with $20 \mathrm{mg} \mathrm{Zn} \mathrm{kg}^{-1}$ soil is comparable to the carbendazim treatment.

\subsection{Morphological Parameters}

3.2.1. Root Length. The root lengths in inoculated seedlings significantly reduced as compared to uninoculated one, 
TABLE 1: Effect of different levels of zinc on the incidence of root rot of guar inoculated with Rhizoctonia species at 15 days after sowing.

\begin{tabular}{lcc}
\hline Treatments & $\begin{array}{c}\text { Rate of application } \\
\left(\mathrm{mg} \mathrm{kg}^{-1} \text { soil }\right)\end{array}$ & $\begin{array}{c}\text { Disease incidence } \\
(\%)\end{array}$ \\
\hline Zinc (control) & 0 & 68 \\
Zinc & 10 & 41 \\
Zinc & 20 & 27 \\
Carbendazim ${ }^{*}$ & $0.2 \%$ & 27 \\
SE (m) & & 0.198 \\
C.D. 5\% & & 0.555
\end{tabular}

${ }^{*}$ Seeds were treated with carbendazim at the rate of $2 \mathrm{~g} \mathrm{~kg}^{-1}$ and sown in unamended soil; each value is the mean of three replications.

TABLE 2: Effect of different levels of zinc on root length $\left(\mathrm{cm} \mathrm{seedling}^{-1}\right)$ of guar seedlings uninoculated and inoculated with Rhizoctonia species at 15 days after sowing. Uninoculated (UI) and inoculated (I).

\begin{tabular}{lccc}
\hline Treatments & $\begin{array}{c}\text { Rate of application } \\
\left(\mathrm{mg} \mathrm{kg}^{-1} \text { soil) }\right.\end{array}$ & \multicolumn{2}{c}{ Root length } \\
\hline Zinc (control) & 0 & 3.78 & 3.05 \\
Zinc & 10 & 3.34 & 3.32 \\
Zinc & 20 & 3.87 & 3.65 \\
Carbendazim* & $0.2 \%$ & 4.14 & 3.82 \\
SE (m) & & 0.102 & 0.240 \\
C.D. 5\% & & 0.290 & 0.660 \\
\hline
\end{tabular}

Each value is the mean of three replications.

* Seeds were treated with carbendazim at the rate of $2 \mathrm{~g} \mathrm{~kg}^{-1}$ and sown in unamended soil.

TABLE 3: Effect of different levels of zinc on the content of zinc ( $\mathrm{mg} \mathrm{kg}^{-1}$ soil) on dry weight basis in roots of guar seedlings uninoculated and inoculated with Rhizoctonia species at 15 days after sowing. Uninoculated (UI) and inoculated (I).

\begin{tabular}{lccc}
\hline Treatments & $\begin{array}{c}\text { Rate of application } \\
\left(\mathrm{mg} \mathrm{kg}^{-1} \text { soil }\right)\end{array}$ & UI & I \\
\hline Zinc (control) & 0 & 13.5 & 23.5 \\
Zinc & 10 & 20.8 & 24.5 \\
Zinc & 20 & 31.5 & 47.0 \\
Carbendazim & $0.2 \%$ & 60.8 & 74.0 \\
SE (m) & & 0.042 & 0.098 \\
C.D. 5\% & & 0.119 & 0.279 \\
\hline
\end{tabular}

Each value is the mean of three replications.

${ }^{*}$ Seeds were treated with carbendazim at the rate of $2 \mathrm{~g} \mathrm{~kg}^{-1}$ and sown in unamended soil.

which showed dwarfness promoting tendency of Rhizoctonia species (Table 2). The similar trend was also obtained with carbendazim treatment.

In uninoculated and inoculated seedlings, a regular trend was obtained for the root length; that is, root length increased with increase in zinc concentration, which showed that zinc imposed positive effect on root length.
TABLE 4: Effect of different levels of zinc on the content of zinc ( $\mathrm{mg} \mathrm{kg}^{-1}$ soil) on dry weight basis in leaves of guar seedlings uninoculated and inoculated with Rhizoctonia species at 15 days after sowing. Uninoculated (UI) and inoculated (I).

\begin{tabular}{lccc}
\hline Treatments & $\begin{array}{c}\text { Rate of application } \\
\left(\mathrm{mg} \mathrm{kg}^{-1} \text { soil) }\right.\end{array}$ & UI & I \\
\hline Zinc (control) & 0 & 60.3 & 120.8 \\
Zinc & 10 & 68.5 & 89.8 \\
Zinc & 20 & 118.5 & 167.0 \\
Carbendazim* & $0.2 \%$ & 61.0 & 71.0 \\
SE (m) & & 0.021 & 0.050 \\
C.D. 5\% & & 0.060 & 0.141 \\
\hline
\end{tabular}

Each value is the mean of three replications.

${ }^{*}$ Seeds were treated with carbendazim at the rate of $2 \mathrm{~g} \mathrm{~kg}^{-1}$ and sown in unamended soil.

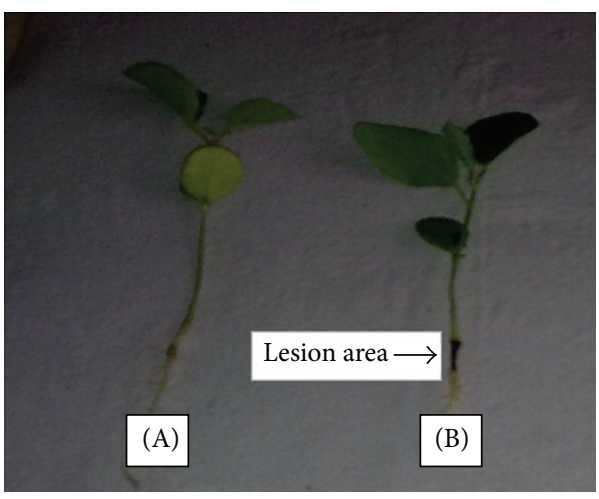

FIGURE 1: Uninoculated (A) and inoculated (B) guar seedlings showing lesion area at 15 DAS.

3.3. Micronutrients. The data presented (Tables 3 and 4) showed regular trend of increase in zinc content in roots and leaves of uninoculated and inoculated seedlings with increase in zinc supplementation in soil. The inoculated roots have increased zinc content as compared with the uninoculated one.

\subsection{Polyphenol Oxidase, Peroxidase, Phenylalanine Ammonia} Lyase and Tyrosine Ammonia Lyase Specific Activity. Specific activity of polyphenol oxidase (PPO), peroxidase (POX), phenylalanine ammonia lyase (PAL), and tyrosine ammonia lyase (TAL) increased with inoculation (Tables 5 and 6) as well as with zinc and carbendazim treatment as compared to control. The specific activity of peroxidase was many fold higher than that of polyphenol oxidase. The enzymatic activities were observed to be higher at $20 \mathrm{mg} \mathrm{Zn} \mathrm{kg}^{-1}$ soil as compared to $10 \mathrm{mg} \mathrm{Zn} \mathrm{kg}^{-1}$ soil treatment.

The specific activities of all the enzymes, namely, PPO, POX, PAL, and TAL were found to be lowest at $0 \mathrm{mg} \mathrm{Zn} \mathrm{kg}^{-1}$ soil in uninoculated as well as inoculated clusterbean seedlings.

At higher zinc concentration, the specific activity of enzymes was also high. Specific activity of polyphenol oxidase (units ${ }^{1}$ ) ranged from 2.81 units and 5.38 units at $0 \mathrm{mg} \mathrm{Zn} \mathrm{kg}{ }^{-1}$ 
TABLE 5: Effect of different levels of zinc on the specific activity of polyphenol oxidase (PPO) and peroxidase $(\mathrm{POX})\left(\times 10^{2}\right)$ in roots of guar seedlings uninoculated (UI) and inoculated (I) with Rhizoctonia species at 15 days after sowing.

\begin{tabular}{|c|c|c|c|c|c|}
\hline \multirow{2}{*}{ Treatments } & \multirow{2}{*}{ Rate of application ( $\mathrm{mg} \mathrm{kg}^{-1}$ soil) } & \multicolumn{2}{|c|}{ PPO (units ${ }^{1}$ ) } & \multicolumn{2}{|c|}{ POX (units ${ }^{1}$ ) } \\
\hline & & UI & $\mathrm{I}$ & UI & I \\
\hline Zinc (control) & 0 & 2.81 & 5.38 & 10.17 & 25.52 \\
\hline Zinc & 10 & 4.16 & 4.78 & 16.50 & 27.97 \\
\hline Zinc & 20 & 4.26 & 6.87 & 29.54 & 34.73 \\
\hline Carbendazim* & $0.2 \%$ & 8.75 & 10.07 & 22.46 & 36.40 \\
\hline $\mathrm{SE}(\mathrm{m})$ & & 0.06 & 0.14 & 0.48 & 1.24 \\
\hline C.D. $5 \%$ & & 0.16 & 0.41 & 1.36 & 3.46 \\
\hline
\end{tabular}

${ }^{*}$ Seeds were treated with carbendazim at the rate of $2 \mathrm{~g} \mathrm{~kg}^{-1}$ and sown in unamended soil; each value of PPO is the mean of three replications and each value of POX is the mean of six replications.

${ }^{1} 1$ unit $=$ change in 0.01 O.D. $\mathrm{min}^{-1} \mathrm{mg}^{-1}$ protein.

TABLE 6: Effect of different levels of zinc on the specific activity of phenylalanine ammonia lyase (PAL) and tyrosine ammonia lyase (TAL) in roots of guar seedlings uninoculated (UI) and inoculated (I) with Rhizoctonia species at 15 days after sowing.

\begin{tabular}{|c|c|c|c|c|c|}
\hline \multirow{2}{*}{ Treatments } & \multirow{2}{*}{ Rate of application ( $\mathrm{mg} \mathrm{kg}^{-1}$ soil) } & \multicolumn{2}{|c|}{ PAL (units ${ }^{2}$ ) } & \multicolumn{2}{|c|}{ TAL (units ${ }^{3}$ ) } \\
\hline & & UI & I & UI & I \\
\hline Zinc (control) & 0 & 2.34 & 4.08 & 1.14 & 1.68 \\
\hline Zinc & 10 & 8.52 & 10.86 & 1.68 & 4.62 \\
\hline Zinc & 20 & 9.78 & 12.48 & 4.02 & 9.06 \\
\hline Carbendazim* & $0.2 \%$ & 8.10 & 16.32 & 6.00 & 14.16 \\
\hline $\mathrm{SE}(\mathrm{m})$ & & 0.10 & 0.250 & 0.043 & 0.094 \\
\hline C.D. $5 \%$ & & 0.29 & 0.720 & 0.119 & 0.260 \\
\hline
\end{tabular}

* Seeds were treated with carbendazim at the rate of $2 \mathrm{~g} \mathrm{~kg}^{-1}$ and sown in unamended soil; each value of PAL and TAL is the mean of three replications.

${ }^{2} 1$ unit $=1 \mu$ mole $t$-cinnamate accumulated $\mathrm{h}^{-1} \mathrm{mg}^{-1}$ protein.

${ }^{3} 1$ unit $=1 \mu$ mole coumaric acid accumulated $\mathrm{h}^{-1} \mathrm{mg}^{-1}$ protein.

soil to 8.75 units and 10.07 units at carbendazim treatment in uninoculated and inoculated seedlings, respectively (Table 5). Specific activity of peroxidase (units ${ }^{1}$ ) ranged from $10.17\left(\times 10^{2}\right)$ units at $0 \mathrm{mg} \mathrm{Zn} \mathrm{kg}^{-1}$ soil to $29.54\left(\times 10^{2}\right)$ units at $20 \mathrm{mg} \mathrm{Zn} \mathrm{kg}^{-1}$ soil in uninoculated guar seedlings, while, in inoculated seedlings, specific activity of POX ranged from $25.52\left(\times 10^{2}\right)$ units at $0 \mathrm{mg} \mathrm{Zn} \mathrm{kg}^{-1}$ soil treatment to 36.40 $\left(\times 10^{2}\right)$ units at carbendazim treatment followed by 34.73 $\left(\times 10^{2}\right)$ units at $20 \mathrm{mg} \mathrm{Zn} \mathrm{kg}^{-1}$ soil treatment.

Also, specific activity of PAL (units ${ }^{2}$ ) was found to be maximum at $20 \mathrm{mg} \mathrm{Zn} \mathrm{kg}^{-1}$ soil treatment with 9.78 units in uninoculated seedlings and at carbendazim treatment with 16.32 units followed by $20 \mathrm{mg} \mathrm{Zn} \mathrm{kg}^{-1}$ soil treatment (12.48 units) in inoculated seedlings (Table 6). Specific activity of TAL (units ${ }^{3}$ ) ranged from 1.14 units to 6.00 units and 1.68 units to 14.16 units from $0 \mathrm{mg} \mathrm{Zn} \mathrm{kg}^{-1}$ soil to carbendazim treatment in uninoculated and inoculated seedlings, respectively, followed by 4.02 and 9.06 units in uninoculated and inoculated seedlings, respectively, at $20 \mathrm{mg} \mathrm{Zn} \mathrm{kg}^{-1}$ soil treatment.

\section{Discussion}

The results indicate that after carbendazim, $20 \mathrm{mg} \mathrm{Zn} \mathrm{kg}^{-1}$ soil treatment was observed to be most effective in promoting resistance in the guar seedlings against root rot disease caused by Rhizoctonia species. This result is in agreement with the results of other researchers in the case of cotton, cowpea, and potato $[12,23,24] . \mathrm{Zn}$ is thought to be involved in checking the growth of the invading fungus by masking the active groups that are necessary for reaction with the enzymes of the fungus [6, 24]. Hassan and Abo-Elyousr [25] also found a positive correlation between suppression of wilt diseases severity and $\mathrm{Zn}$ content in basil plants. In the most positive cases, the application of $\mathrm{Zn}$ reduced disease severity, which could be because of the toxic effect of $\mathrm{Zn}$ on the pathogen directly [26].

The root length increased with $\mathrm{Zn}$ treatment in uninoculated as well as inoculated seedlings (Table 2) which is due to the role of the zinc in the biosynthesis of growth promoting hormone such as indole-3-acetic acid (IAA) [27, 28] and gibberellins [29]. Additionally, zinc is an activator of many enzymes involved in cell elongation and cell division $[28,30]$.

As a result of infection, the zinc status of host plant also gets affected. The observed increase in $\mathrm{Zn}$ content in roots and leaves of the inoculated seedlings (Tables 3 and 4) due to soil treatment with different concentration of zinc might be due to their immobilization, reduced absorptive capacity, and increased translocation. Similar observations had been revealed by Kalim [24] and Nema [31]. The observed increase in zinc content could either be due to their increased translocation or accumulation at infection sites.

The present investigation resulted in increase of the specific activity of the PPO, POX, PAL and TAL in inoculated seedlings (Tables 5 and 6) as compared to the uninoculated 
seedlings. Furthermore, specific activity of POX was many fold higher than that of the PPO. This many fold increase in POX activity is in agreement with the investigation done by Khan et al. [32] in the leaves of infected sorghum and Kumar et al. [33] in Pearl millet. Increased activity of polyphenol oxidase (PPO), peroxidase (POX), phenylalanine ammonia lyase (PAL), and tyrosine ammonia lyases (TAL) had been reported in plants treated with various biotic and abiotic inducers of resistance [33-35]. The specific activities of PAL and TAL were maximum at $\mathrm{Zn}^{2+} 20 \mathrm{ppm}$ which is due to the fact that $\mathrm{Zn}$ acts as a cofactor for PAL and TAL.

\section{Conclusion}

$\mathrm{Zn}^{2+} 20 \mathrm{mg} \mathrm{kg}^{-1}$ soil treatment is observed to induce high activity of antioxidative enzymes, which are found to play an important role against fungal invasion. So, it can be concluded that $\mathrm{Zn}^{2+} 20 \mathrm{mg} \mathrm{kg}^{-1}$ soil treatment, as soilnutritive agent, play an important role in defense mechanism and provide resistance in plants against fungal diseases by enhancing activity of antioxidative enzymes.

\section{Conflict of Interests}

The authors declare that there is no conflict of interests regarding the publication of this paper.

\section{Acknowledgments}

The authors gratefully acknowledge the Director Research for providing the necessary infrastructural facility and are highly thankful to Dr. (Mrs.) Kaushalya Gupta from the Department of Biochemistry, Dr. S. K. Pahuja from the Forage Section, and Dr. S. K. Gandhi from the Department of Pathology, CCS Haryana Agricultural University, Hisar, for their cooperation and for providing the necessary facilities for this investigation.

\section{References}

[1] S. K. Pahuja, P. P. Gupta, U. N. Joshi, R. Yadav, and R. S. Khatri, "Breeding Arid Legumes for tolerance to biotic stresses," in Genetic Improvement For Biotic Stress, S. K. Sethi, A. K. Chhabra, R. Kushal, S. S. Siwach, and D. Singh, Eds., pp. 16-25, Department of Plant Breeding, CCSHAU, Hisar, India, 2010.

[2] J. V. Singh and B. S. Dahiya, "Guar breeding-Global Scenario," in Guar, J. V. Singh and B. S. Dahiya, Eds., pp. 10-33, Indian Society of Forage Research, Hisar and APEDA, New Delhi, India, 2004.

[3] A. Garibaldi, M. L. Gullino, and G. Minuto, "Diseases of basil and their management," Plant Disease, vol. 81, pp. 124-132, 1997.

[4] J.-P. Toussaint, M. Kraml, M. Nell et al., "Effect of Glomus mosseae on concentrations of rosmarinic and caffeic acids and essential oil compounds in basil inoculated with Fusarium oxysporum f.sp. basilici," Plant Pathology, vol. 57, no. 6, pp. 11091116, 2008.

[5] S. A. Al-Sohaibani, M. A. Mahmoud, M. R. Al-Othman, M. M. M. Ragab, M. M. Saber, and A. R. M. Abd El-Aziz, "Influence of some biotic and abiotic inducers on root rot disease incidence of sweet basil," African Journal of Microbiology Research, vol. 5, no. 22, pp. 3628-3639, 2011.

[6] H. R. Kataria, J. P. S. Yadav, and R. K. Grover, "Interaction of chemical fertilizers with seed dressing fungicides in controlling Rhizoctonia solani," PfIaschutz, vol. 88, pp. 641-650, 1981.

[7] A. A. Aly, M. R. Omar, S. Abdel, A. Mohmed, E. Abd, and A. Kamel, "Effect of physical and chemical factors on susceptibility of cotton seedlings to Macrophomina phaseolina," Pest Technology, vol. 2, pp. 1-4, 2008.

[8] N. G. Agrios, Plant Pathology, Elsevier, Amsterdam, The Netherlands, 5th edition, 2005.

[9] Z. I. S. Karaklajic-Stajic, D. Glisic, T. Ruzic, and M. P. Vujovic, "Microelements content in leaves of raspberry cv. Willamette as affected by foliar nutrition and substrates," Horticultural Science, vol. 2, pp. 67-73, 2012.

[10] D. M. Huber and S. Haneklaus, "Managing nutrition to control plant disease," Landbauforschung Volkenrode, vol. 57, no. 4, pp. 313-322, 2007.

[11] L. E. Datnof, W. Elmer, and D. M. Huber, Mineral Nutrition and Plant Disease, APS press, St. Paul, Minn, USA, 2007.

[12] P. K. Samant, "Zinc: an essential micronutrient for crop production,” Orissa Review, pp. 85-87, 2009.

[13] A. H. Khoshgoftarmanesh, S. Kabiri, H. Shariatmadari, B. Sharifnabi, and R. Schulin, "Zinc nutrition effect on the tolerance of wheat genotypes to Fusarium root-rot disease in a solution culture experiment," Soil Science and Plant Nutrition, vol. 56, no. 2, pp. 234-243, 2010.

[14] R. F. Brennan, "The role of manganese and nitrogen nutrition in the susceptibility of wheat plants to take-all in Western Australia," Fertilizer Research, vol. 31, no. 1, pp. 35-41, 1992.

[15] D. M. Huber and R. D. Graham, "The role of nutrition in crop resistance and tolerance to disease," in Mineral Nutrition of Crops Fundamental Mechanisms and Implications, Z. Rengel, Ed., pp. 205-226, Food Product Press, New York, NY, USA, 1999.

[16] J. R. Heckman, B. B. Clarke, and J. A. Murphy, “Optimizing manganese fertilization for the suppression of take-all patch disease on creeping bentgrass," Crop Science, vol. 43, no. 4, pp. 1395-1398, 2003.

[17] K. B. Simoglou and C. Dordas, "Effect of foliar applied boron, manganese and zinc on tan spot in winter durum wheat," Crop Protection, vol. 25, no. 7, pp. 657-663, 2006.

[18] S. R. Taneja and R. C. Sachar, "Induction of polyphenol oxidase in germinating wheat seeds," Phytochemistry, vol. 13, no. 12, pp. 2695-2702, 1974.

[19] L. M. Shannon, E. Kay, and J. Y. Lew, "Peroxidase isozymes from horseradish roots. I: isolation and physical properties," Journal of Biological Chemistry, vol. 241, no. 9, pp. 2166-2172, 1966.

[20] W. L. Biehn, J. Kue, and E. B. Williams, "Accumulation of phenols in resistant plant-fungi interaction," Phytopathology, vol. 58, pp. 1255-1260, 1968.

[21] D. H. Lowry, N. J. Rosebrough, A. L. Farr, and J. L. Randall, "Protein measurement with the Folin phenol reagent," The Journal of biological chemistry, vol. 193, no. 1, pp. 265-275, 1951.

[22] O. P. Sheoran, "Statistical analysis software," http://www.hau .ernet.in.

[23] A. K. Somani, "Non-hazardous chemical control of black scurf (Rhizoctonia solani) and common scab (Streptomyces scabies) of potato (Solanum tuberosum) with boric acid," Indian Journal of Agricultural Sciences, vol. 56, pp. 366-369, 1986. 
[24] S. Kalim, Micronutrients induced effect on biochemical constituents in cowpea susceptible to Rhizoctonia solani and Rhizoctonia bataticola [M.S. thesis], Haryana Agricultural university, Hisar, India, 2003.

[25] M. A. E. Hassan and K. A. M. Abo- Elyousr, "Impact of compost application on Fusarium wilt disease incidence and microelements contents of basil plants," Archieves of Phytopathology and Plant Protection, vol. 46, no. 16, 2013.

[26] D. R. Graham and M. J. Webb, "Micronutrients and disease resistance and tolerance in plants," in Micronutrients in Agriculture, J. J. Mortvedt, F. R. Cox, L. M. Schuman, and R. M. Welch, Eds., pp. 329-370, Soil Science Society of America, Madison, Wis, USA, 2nd edition, 1991.

[27] I. K. Garg, A. Hermantaranjan, and C. Ramesh, "Effect of iron and zinc fertilization on senescence in French bean," Plant Nutrition, vol. 9, pp. 257-266, 1986.

[28] I. Cakmak, "Tansley review no. 111: possible roles of zinc in protecting plant cells from damage by reactive oxygen species," New Phytologist, vol. 146, no. 2, pp. 185-205, 2000.

[29] H. Suge, H. Takahashi, S. Arita, and H. Takaki, "Gibberellin relationships in zinc-deficient plants," Plant and Cell Physiology, vol. 27, no. 6, pp. 1005-1012, 1986.

[30] Q. Yu, C. Worth, and Z. Rengel, "Using capillary electrophoresis to measure $\mathrm{Cu} / \mathrm{Zn}$ superoxide dismutase concentration in leaves of wheat genotypes differing in tolerance to zinc deficiency," Plant Science, vol. 143, no. 2, pp. 231-239, 1999.

[31] A. G. Nema, "Varietal resistance in betelvine against Xanthomonas campestris pv. betlicola and its manipulation with crop nutrients," Indian Phytopathology, vol. 41, pp. 344-350, 1988.

[32] A. J. Khan, M. L. Deadman, A. Srikandakumar, Y. M. AlMaqbali, S. G. Rizvi, and J. Al-Sabahi, "Biochemical changes in Sorghum leaves infected with leaf spot pathogen Drechslera sorghicola," The Plant Pathology Journal, vol. 17, no. 6, pp. 342346, 2001

[33] A. Kumar, P. C. Mali, and V. K. Manga, "Changes of some phenolic compounds and enzyme activities on infected pearl millet caused by Sclerospora graminicola," International Journal of Plant Physiology and Biochemistry, vol. 2, no. 1, pp. 6-10, 2010.

[34] L. D. Huang and D. Backhouse, "Induction of defense responses in roots and mesocotyls of sorghum seedlings by inoculation with Fusarium thapsinum and Fusarium proliferatum," Journal of Phytopathology, vol. 153, pp. 522-529, 2005.

[35] V. B. Raghavendra, S. Lokesh, M. Govindappa, and T. VasanthKumar, "Dravya-As an organic agent for the management of seed-borne fungi of sorghum and its role in the induction of defense enzymes," Pesticide Biochemistry and Physiology, vol. 89, no. 3, pp. 190-197, 2007. 

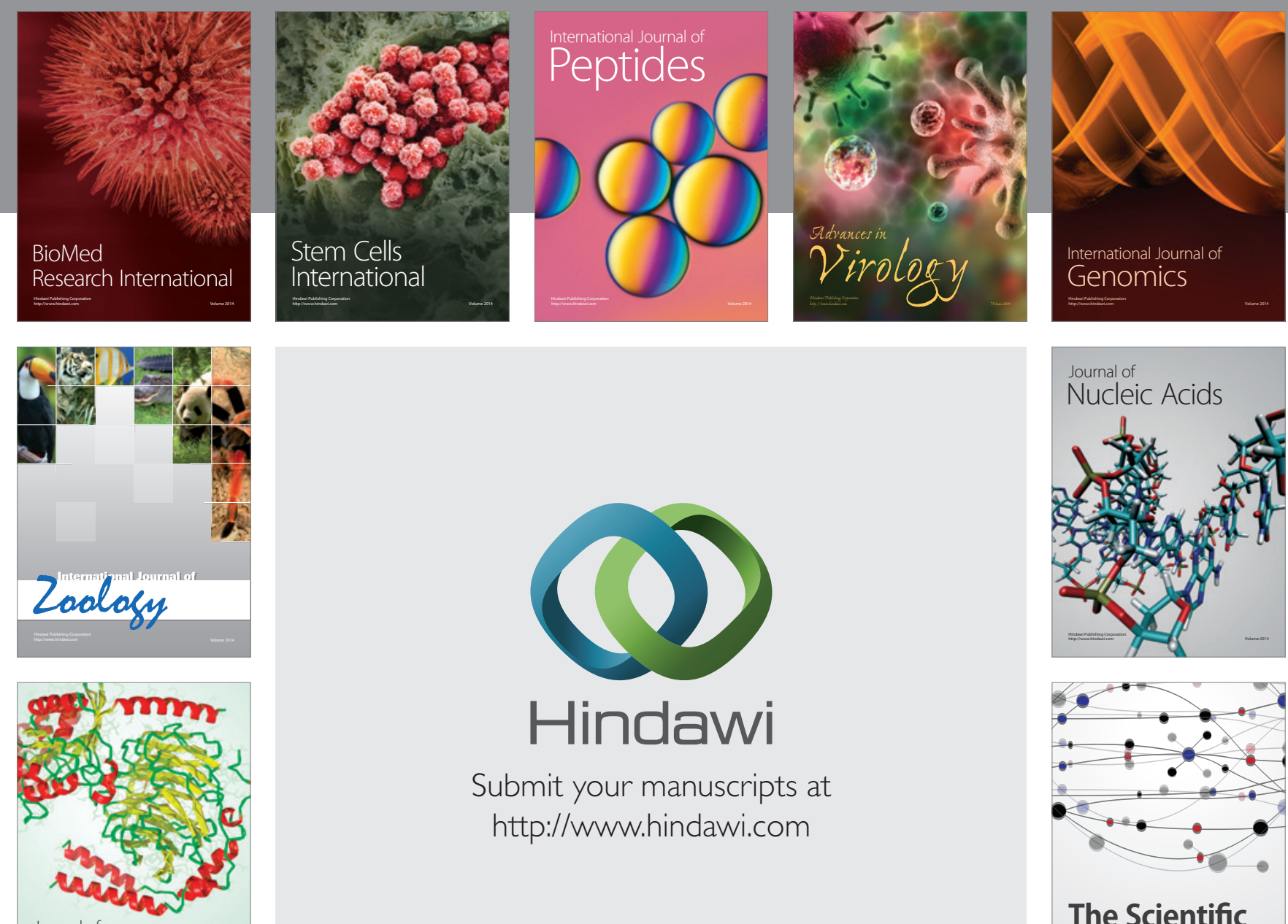

Submit your manuscripts at

http://www.hindawi.com

Journal of
Signal Transduction
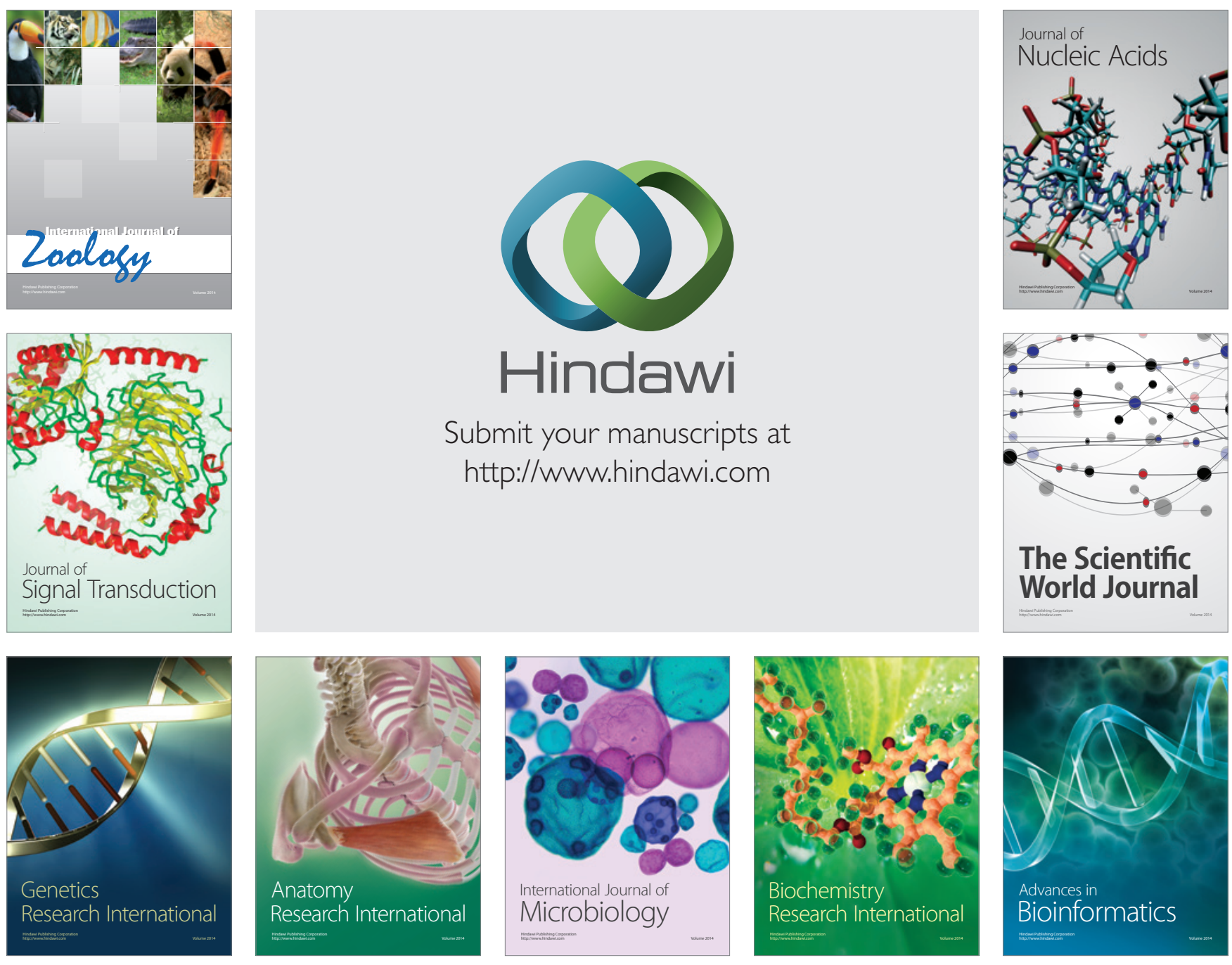

The Scientific World Journal
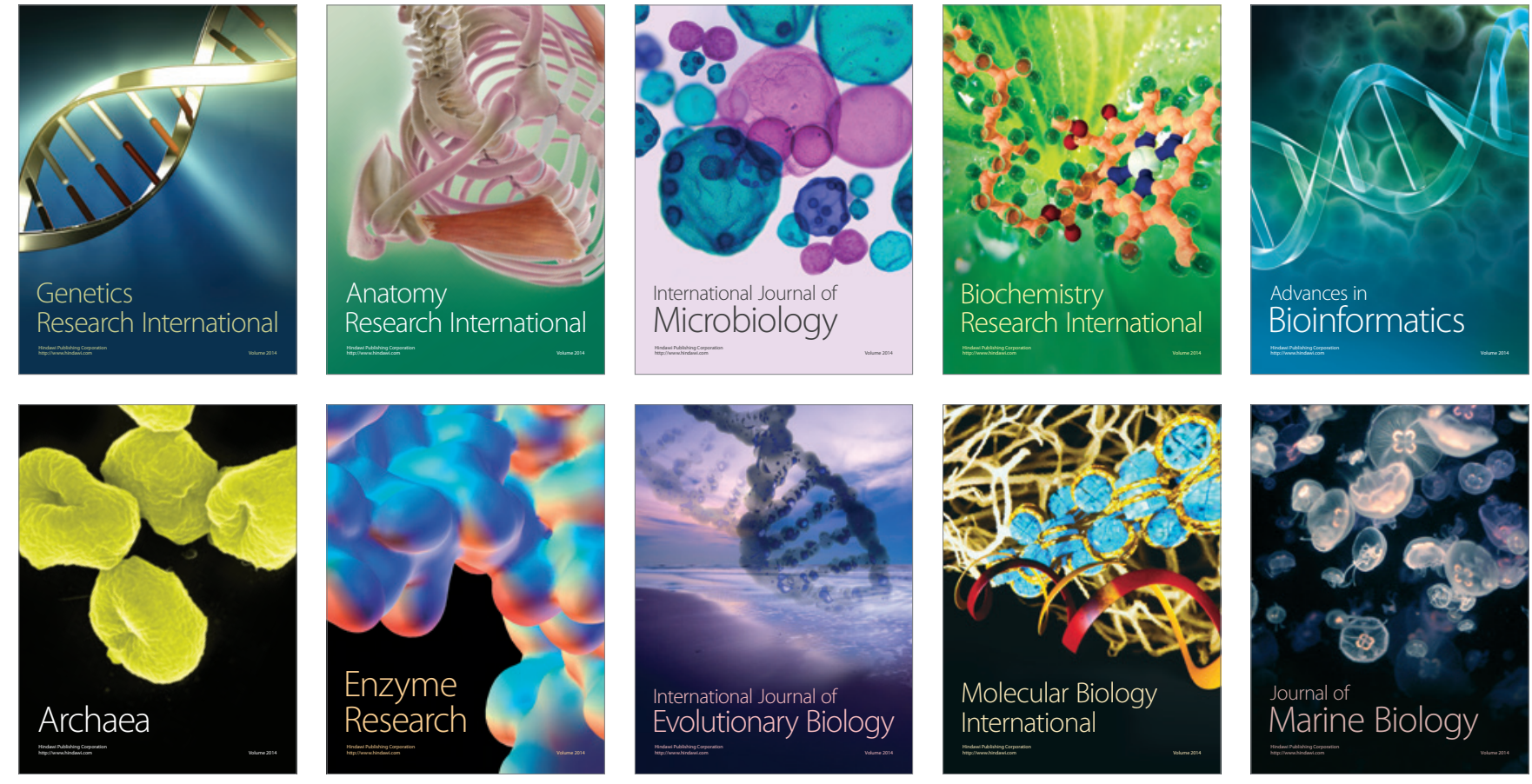